\title{
ANALISIS RESTITUSI PAJAK PERTAMBAHAN NILAI PADA KEPATUHAN PENGUSAHA KENA PAJAK KANTOR PELAYANAN PAJAK PRATAMA (KPP CIREBON TAHUN 2016-2018)
}

\author{
Endah Nurhawaeny Kardiyati ${ }^{1}$, Abdul Karim ${ }^{2}$ \\ 1) Fakultas Ekonomi, Universitas Muhammadiyah Cirebon \\ 2)Fakultas Keguruan dan Ilmu Pendidikan, Universitas Muhammadiyah Cirebon
}

\begin{abstract}
ABSTRAK
This study aims to analyze the mechanism of value added tax restitution and the obstacles that often occur during the restitution process. The method used in this research is descriptive method with a qualitative approach, and using embedded case study research case studies. The results of this study are the mechanism of value added tax restitution at the Pratama Cirebon tax service office carried out in accordance with applicable rules and obstacles that often occur in the process of value added tax restitution on taxpayers.
\end{abstract}

$\begin{array}{ll}\text { Keywords } & \text { : Restitution; Value Added Tax } \\ \text { Correspondence to } & \text { : karim_gml81@yahoo.co.id }\end{array}$

\section{ABSTRAK}

Penelitian ini bertujuan untuk menganalisis mekanisme restitusi pajak pertambahan nilai dan kendala yang sering terjadi pada saat proses restitusi. Metode yang digunakan dalam penelitian ini adalah metode deskriptif dengan pendekatan kualitatif, dan menggunakan studi kasus embedded case study research. Hasil dari penelitian ini adalah mekanisme restitusi pajak pertambahan nilai pada kantor pelayanan pajak pratama cirebon dilakukan sesuai dengan aturanaturan yang berlaku dan kendala yang sering terjadi dalam proses restitusi pajak pertambahan nilai pada wajib pajak.
Kata kunci
: Restitusi; Pajak Pertambahan Nilai.
Korespondensi
:karim_gm181@yahoo.co.id

\section{PENDAHULUAN}

Pajak merupakan sumber utama penerimaan negara untuk membiayai semua pengeluaran negara terutama dalam pembiayaan pembangunan dan peningkatan kesejahteraan dalam segala bidang. Maka dari itu peran dari masyarakat sangat diperlukan dalam bentuk kesadaran membayar pajak. Pajak bersifat memaksa dan legal, maka dari itu pemerintah memiliki kekuatan hukum (denda) untuk menindak tegasi wajib pajak yang tidak memenuhi kewajibannya dalam 


\section{BALANCE : Economic, Business, Management, and Accounting J ournal Vol. XVII No. 2 |Bulan J uli Tahun 2020}

membayar pajak. Manfaat pajak tidak dapat dinikmati secara langsung melainkan dapat dinikmati masyarakat melalui pembangunan sarana dan prasarana untuk kepentingan umum masyarakat yang diberikan oleh negara. Walaupun demikian, manfaat pajak berjangka waktu panjang. Pajak pertambahan nilai (PPN) adalah salah satu iuran wajib pajak yang harus dipenuhi oleh wajib pajak saat melakukan transaksi penjualan barang dan jasa, dan pajak pertambahan nilai barang mewah.

Pajak Pertambahan Nilai (Value Added Tax ) adalah nilai tambah yang dikenakan atas setiap penjualan barang atau jasa, PPN termasuk pajak tidak langsung yang dikenakan atas setiap transaksi penjualan baik barang kena pajak (BKP) maupun jasa kena pajak (JKP) oleh penjual (PKP) kepada pembeli yang disetorkan melalui penjual barang atau jasa.PPN pertama kali dikenalkan oleh Carl Friedriech Von Siemens, yaitu seorang industrialis dan konsultan pemerintah Jerman pada tahun 1919. Namun sayangnya, Pemerintah Prancis lebih dulu menerapkan Pajak Pertambahan Nilai dalam sistem perpajakan dibanding Jerman. Pada tahun 1983, Indonesia sudah menerapkan PPN, yang diatur dalam Undang-Undang Nomor 8 Tahun 1983 tentang Pajak Pertambahan Nilai Barang dan Jasa dan Pajak Penjualan atas Barang Mewah. Dan kemudian pada 1 April 1985, terjadi perubahan pada UndangUndang Nomor 8 Tahun 1983. Apabila terjadi kelebihan pembayaran pajak pertambahan nilai sebagaimana yang dilaporkan dalam surat pemberitahuan (SPT) atau terdapat kekeliruan dalam pemungutan atau pemotongan yang menyebabkan kelebihan pembayaran pajak, Hak ini dapat ditunaikan setelah mengajukan permohonan yang ditindak lanjuti dengan pemeriksaan dan penelitian atas kebenaran pembayaran pajak tergantung dari status permohonan tersebut. Hal tersebut biasa disebut dengan Restitusi
Pajak Pertambahan Nilai, secara sederhana dalam restitusi pajak negara harus mengembalikan pajak yang telah dibayarkan oleh wajib pajak atas terjadinya kelebihan pembayaran pajak. Hal ini dilakukan untuk melindungi hak wajib pajak.

Pada tahun 2018, dari 5.730 hanya 156 yang melakukan restitusi dan bulan januari hingga mei 2019 kemarin, dari 1.687 hanya 112 yang melakukan restitusi di kantor pelayanan pajak pratama cirebon 1. Hal tersebut menjadi perhatian penulis, baik dari mekanisme hingga kendala yang sering dialami saat melakukan restitusi pajak pertambahan nilai. Dari uraian diatas, penulis tertarik mengambil judul "Analisis restitusipajak pertambahan nilai pada kantor pelayanan pajak pratama Cirebon".

Berdasarkan latar belakang yang telah diuraikan diatas, maka penulis mengidentifikasi masalah yang ada sebagai berikut: (1) Mekanisme restitusi pajak pertambahan nilai kepada pengusaha kena pajak. Dan (2) kendala yang dihadapi saat proses retitusi pajak pertambahan nilai pada wajib pajak dan bagaimana solusinya.

Mengingat banyaknya perkembangan yang bisa ditemukan dalam permasalahan ini, maka perlu adanya batasan-batasan masalah yang jelas mengenai penelitian yang dilakukan. Adapun batasan-batasan masalah dalam penelitian ini adalah sebagai berikut: (1) Data difokuskan pada mekanisme restitusi pajak pertambahan nilai, kendala yang terkait restitusi pajak pertambahan nilai dan solusinya. (2) Data yang akan diambil dari kantor pelayanan pajak pratama cirebon. dan (3) penelitian ini menggunakan metode deskriptif berbentuk narasi dengan pendekatan kualitatif.

Berdasarkan latar belakang yang telah diuraikan diatas, maka perumusan masalah yang akan diteliti: (1) Bagaimana mekanisme restitusi pajak pertambahan nilai kepada pengusaha kena pajak? (2) Apa saja kendala 


\section{BALANCE : Economic, Business, Management, and Accounting J ournal}

Vol. XVII No. 2 |B ulan J uli Tahun 2020

yang dihadapi terkait restitusi pajak pertambahan nilai pada wajib pajak dan bagaimana solusinya?

\section{METODE PENELITIAN}

Penelitian ini menggunakan metode Deskriptif dengan pendekatan kualitatif dan menggunakan studi kasus embedded case study research atau yang biasa disebut studi kasus terpancang. Adapun tahapan yang dilakukan dalam penelitian sebagai berikut:

(1) Mengambil data yang diperlukan dari kantor pelayanan pajak pratama cirebon. (2) Melakukan identifikasi bagaimana mekanisme Restitusi pajak pertambahan nilai pada kantor pelayanan pajak pratama cirebon. (3) Melakukan identifikasi hambatanhambatan yang ditemukan di kantor pelayanan pajak pratama cirebon dalam melakukan restitusi pajak pertambahan nilai. (4) Melakukan identifikasi upaya-upaya yang dilakukan dalam mengatasi hambatanhambatan yang ada di kantor pelayanan pajak pratama cirebon. (5) Mengolah data yang diperoleh dari kamtor pelayanan pajak pratama cirebon. (6) Melaporkan hasil dari penelitian yang dilakukan oleh peneliti.

\section{Definisi Pajak}

Kita semua pasti sering mendengar kata pajak dalam kehidupan sehari-hari, baik pajak kendaraan bermotor, pajak bumi dan bangunan ataupun pajak penghasilan. Bahkan produk yang sering kita konsumsi pun hampir semua terkena pajak. Pengertian pajak sendiri adalah kontribusi wajib rakyat kepada negara yang terutang, baik sebagai pribadi maupun badan usaha yang bersifat memaksa berdasarkan undang-undang dan tidak memberikan manfaat langsung dan digunakan negara untuk keperluan negara guna mensejahterakan rakyat.

Definisi Pajak Pertambahan Nilai

Pajak Pertambahan Nilai (PPN) pertama kali dikenalkan oleh Carl Friedriech
Von Siemens, yaitu seorang industrialis dan

konsultan pemerintah Jerman. Namun sayangnya, Pemerintah Prancis lebih dulu menerapkan Pajak Pertambahan Nilai dalam sistem perpajakan dibanding Jerman. Prancis sebagai negara pertama yang mengadopsi pajak pertambahan nilai tahun 1984 pada tingkat pedagang besar yang akhirnya diperluas sampai pada penyerahan barang yang dilakukan pada tingkat pedagang eceran. Dan Vietnam sebagai negara dilingkungan asia pertama kali menerapkan PPN, yaitu tahun 1984. Sedangkan Indonesia menerapkan PPN pada awal april 1985 bersamaan dengan negara lainnya, yaitu Turki. Pengertian PPN sendiri adalah nilai tambah yang dikenakan atas setiap penjualan barang atau jasa, PPN termasuk pajak tidak langsung yang dikenakan atas setiap transaksi penjualan baik barang kena pajak (BKP) maupun jasa kena pajak (JKP) oleh penjual (PKP) kepada pembeli yang disetorkan melalui penjual barang atau jasa.

\section{Definisi Restitusi Pajak Pertambahan Nilai}

Menurut Djuanda \& Lubis (2011: 121) menyatakan bahwa restitusi merupakan kelebihan pembayaran pajak pertambahan nilai, terjadi karena jumlah pajak masukan yang dibayar lebih besar dari pada jumlah pajak keluaran yang dipungut dalam suatu masa pajak. Sedangkan menurut peraturan pemerintah No. 3 Tahun 2002 pasal 1 angka 5, Restitusi adalah ganti kerugian yang diberikan kepada korban atau keluarganya oleh pelaku atau pihak ketiga, dapat berupa pengembalian harta milik, pembayaran ganti kerugian untuk kehilangan atau penderitaan atau penggantian biaya untuk tindakan tertentu. Jadi restitusi pajak pertambahan nilai adalah pengembalian kelebihan pembayaran pajak pertambahan nilai oleh negara kepada wajib pajak, atau dari Direktorat Jendral Pajak (DJP) kepada Pengusaha Kena Pajak (PKP). Restitusi terjadi apabila jumlah 
Vol. XVII No. 2 |Bulan J uli Tahun 2020

pembayaran ppn yang disetorkan lebih besar dibanding jumlah ppn yang terutang.

Kerangka Berfikir

Menurut peraturan perundangundangan yang telah ditetapkan, wajib pajak diharuskan melakukan pemungutan atau pemotongan pajak tertentu. Dimana setiap perusahaan yang melakukan suatu kegiatan usaha baik barang dan jasa, wajib menyetorkan pajak atas usahanya. Dengan dilakukannya pengrestitusian pajak pertambahan nilai maka berpengaruh terhadap penerimaan pajak pertambahan nilai.

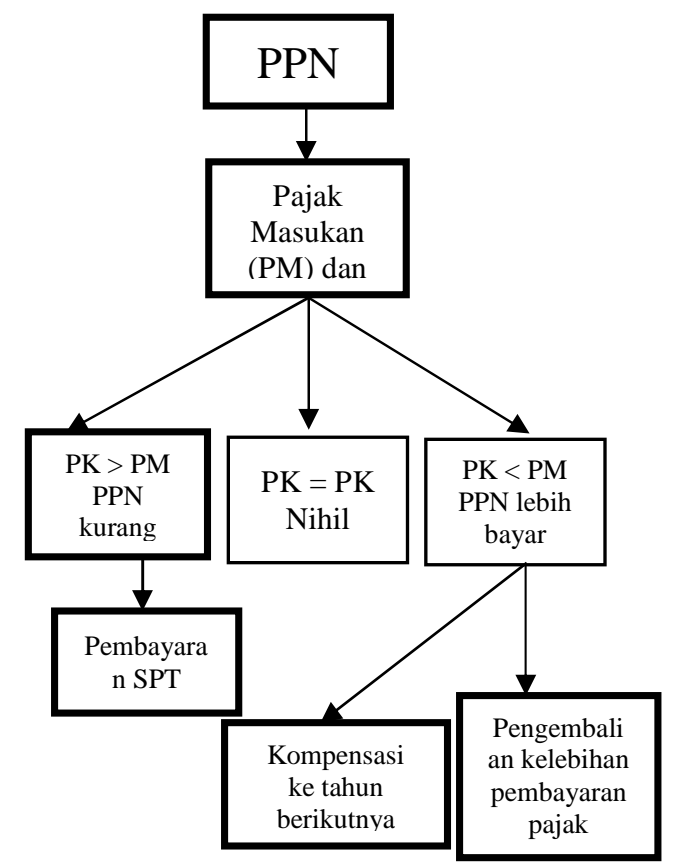

Sumber : Icha Yusadi (2018)

Gambar 1: Kerangka Pemikiran

Pajak Pertambahan Nilai (PPN) terbagi menjadi dua yaitu Pajak Masukan (PM) dan Pajak Keluaran (PK). Apabila Pajak Masukan yang dibayar lebih besar dari pada Pajak Keluaran yang dipungut maka terjadilah PPN lebih bayar. Atau sebaliknya, apabila Pajak Masukan yang dibayar lebih kecil dari pada Pajak Keluaran maka yang terjadi adalah PPN kurang bayar. Maka dari itu antara Pajak Masukan dengan Pajak Keluaran harus sama. PPN yang kurang bayar bisa melakukan pembayaran SPT, dan PPN yang lebih bayar bisa melakukan restitusi atau

dikompensasikan ke tahun berikutnya.

\section{HASIL PENELITIAN}

Mekanisme Restitusi

Dari Flowchart pada tabel 1, dapat penulis uraikan sebagai berikut, Dalam proses restitusi pajak pertambahan nilai terdapat 4 bagian yang bersangkutan dan 4 tahapan yang harus dilalui yaitu:

1. 4 Bagian yang bersangkutan berikut tugas yang terkait dengan proses restitusi pajak pertambahan nilai :

a. Wajib Pajak: (a) Mengajukan Surat Permohonan (SPT PPN LB) dan lampirannya. (b) Menerima surat ketetapan pajak

b. Seksi Pelayanan: (a) Menerima Surat Permohonan dari wajib pajak. (b) Mengolah SPT Masa. (c) Menerbitkan Surat Ketetapan Lebih Bayar (SKPLB). (d) Menyampaikan Surat Perintah Membayar Kelebihan Pajak (SPMKP) kepada kantor pelayanan pembendaharaan negara

c. Seksi Pemeriksaan: (a) Memeriksa SPT Masa PPN Lebih Bayar. (b) Menerbitkan Nota Hitung (Nothit) dan Laporan Hasil Pemeriksaan yang selanjutnya akan diserahkan ke Seksi pelayanan

d. Seksi Pengawasan dan Konsultasi. Menerbitkan Surat Perintah Membayar Kelebihan Pajak yang selanjutnya akan diserahkan kepada seksi pelayanan.

2. 4 tahapan yang dilakukan saat melakukan restitusi pajak pertambahan nilai adalah sebagai berikut :

a. Tahap Permohonan: (a) Pemohon yang memiliki kelebihan bayar (restitusi) dapat mengajukan restitusi ataupun kompensasi ke 

Vol. XVII No. 2 |B ulan J uli Tahun 2020

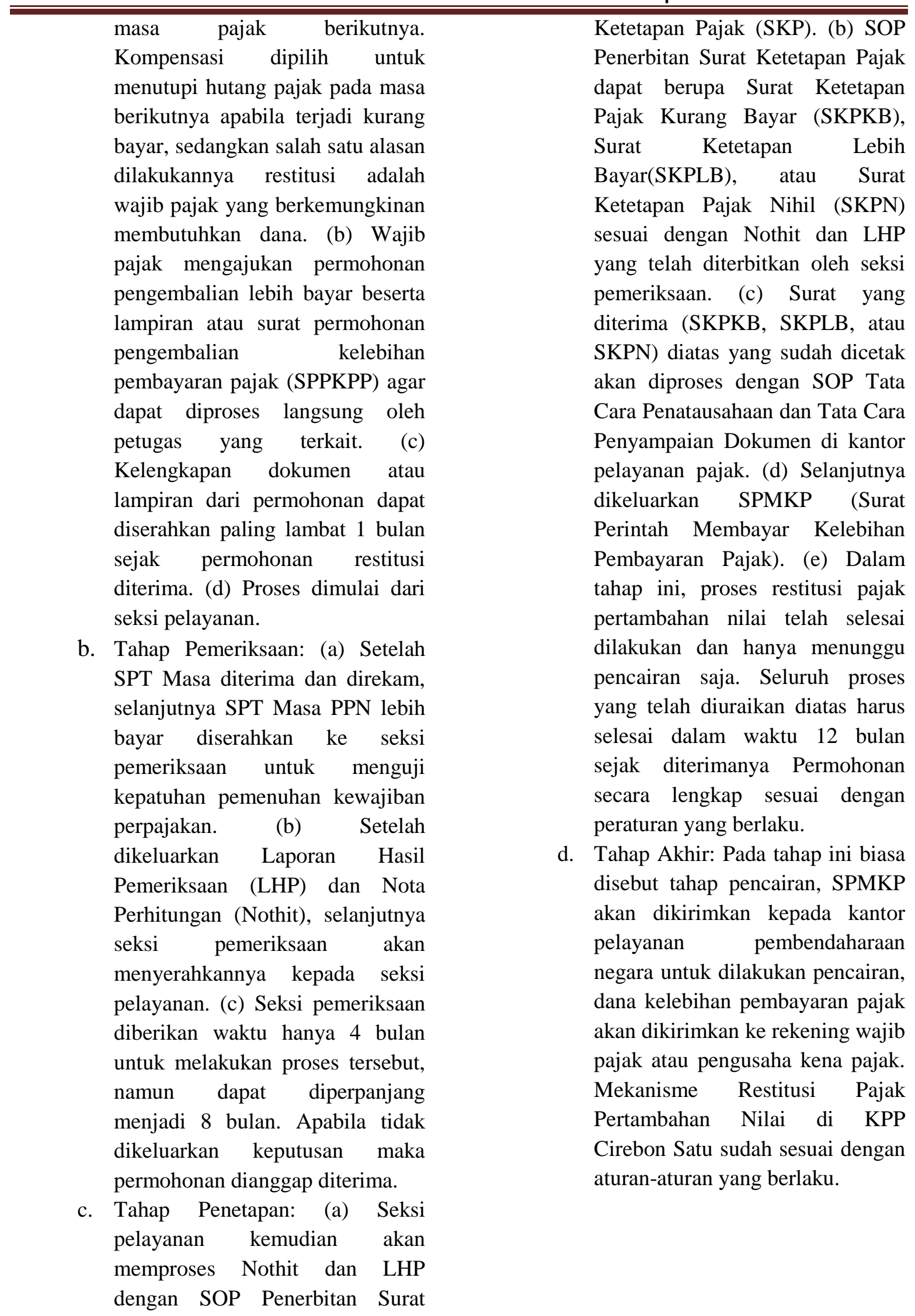


TABEL 1 : Flowchart Proses Restitusi Pajak Pertambahan Nilai

Wajib Pajak

(WP)
Seksi Pelayanan
Seksi Pemeriksaan
Seksi Pengawasan dan

Konsultasi

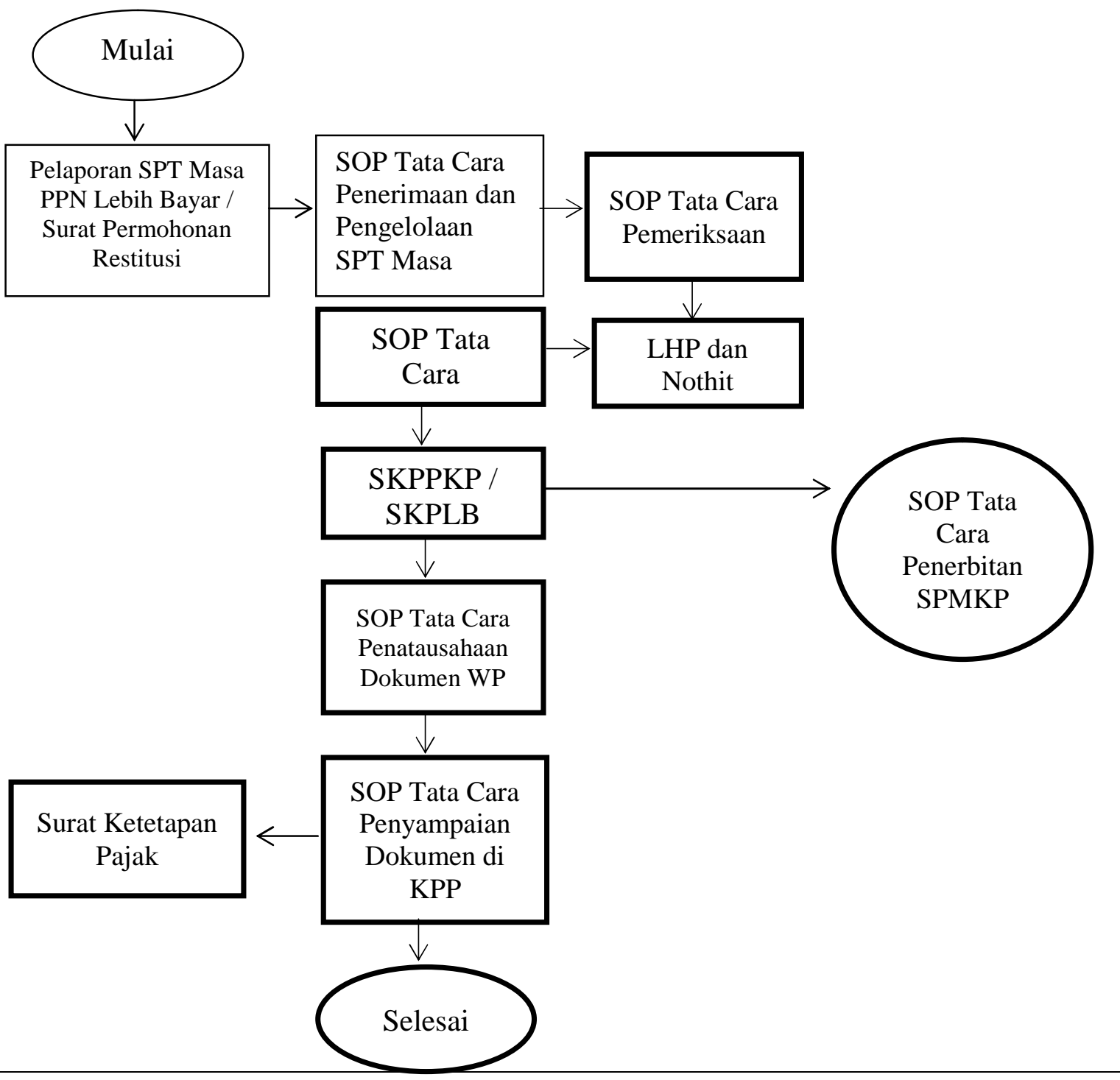

Sumber Flowchart : Juventus Sianturi, 2016

Kendala wajib pajak saat melakukan restitusi pajak pertambahan nilai

Kendala yang ada di wajib pajak adalah pada saat proses pemeriksaan yang memerlukan beberapa data dan memakan waktu yang lama. Hal ini membuat banyak wajib pajak lebih memilih untuk melakukan kompensasi ke masa pajak berikutnya dibandingkan dengan restitusi karna dinilai mudah dilakukan dan tidak menyita banyak waktu. Sedangkan Restitusi memerlukan banyak hal untuk diperiksa, hal tersebut terkait dengan dokumen-dokumen yang harus diserahkan untuk diperiksa, membuat wajib 


\section{BALANCE : Economic, Business, Management, and Accounting J ournal Vol. XVII No. 2 |Bulan J uli Tahun 2020}

pajak harus mengeluarkan data yang sudah di arsip. Kebanyakan Restitusi dilakukan wajib pajak apabila wajib pajak memerlukan dana tersebut.

Dalam kendala ini juga sulit untuk menemukan solusi yang tepat, namun apabila pemerintah mengubah kebijakan tentang restitusi ini menjadi lebih mudah dan tidak memakan banyak waktu, mungkin banyak wajib pajak yang akan melakukan restitusi.

\section{KESIMPULAN}

Dari penelitian yang telah penulis lakukan, maka penulis mengambil suatu kesimpulan. Pertama, mekanisme restitusi pajak pertambahan nilai di kantor pelayanan pajak pratama 1 cirebon dilakukan sesuai dengan aturan-aturan yang berlaku, meskipun terdapat kendala-kendala namun KPP 1 cirebon bisa menyelesaikan kendala tersebut dengan baik. Namun masih banyak wajib pajak yang memilih mengkompensasikan kelebihan bayar pajak pertambahan nilai dikarenakan proses yang memakan waktu.Pasal yang terkait dengan mekanisme restitusi pajak pertambahan nilai adalah pasal 17 ayat $(1,2,3)$, Pasal 17B ayat (1) dan Pasal 17C ayat (1). Kedua, Kendala yang sering dialami saat melakukan restitusi pajak pertambahan nilai menurut wajib pajak sendiri adalah lamanya proses restitusi membuat wajib pajak lebih memilih kompensasi kelebihan tersebut karna dinilai lebih mudah dibanding restitusi. Pada kendala ini juga tidak ditemukan solusinya terkecuali apabila pemerintah memperbarui kebijakan tentang proses restitusi yang lebih mudah namun tetap mewaspadai unsur negatif terkait proses restitusi pajak.

Dari kesimpulan diatas, maka penulis memberikan saran kepada pihak-pihak terkait diharapkan masyarakat khususnya Wajib Pajak (WP) dan Pengusaha Kena Pajak(PKP) yang mempunyai usaha terhadap barang kena pajak dapat memahami pentingnya pajak dan juga mempelajari hal-hal tentang pajak secara khusus mengenai restitusi pajak yang nantinya akan membantu wajib pajak atau pengusaha kena pajak itu sendiri.

Untuk peneliti selanjutnya yang akan melakukan penelitian dengan judul yang sama, disarankan untuk lebih menggali informasi lebih mengenai restitusi ppn dikarenakan keterbatasan penulis dalam melakukan penelitian yang dinilai kurang lengkap.

\section{DAFTAR PUSTAKA}

Djuanda \& Lubis. 2011. Pelaporan Pajak Pertambahan Nilai \& Pajak Penjualan Atas

Barang Mewah. Edisi Revisi 2011. Penerbit PT Gramedia Pustaka Utama, Jakarta.

Diana Sari. 2013. Konsep Dasar Perpajakan. Penerbit PT Refika Adimata, Bandung.

Handayani, Rani. 2016. Analisis Restitusi Pajak Pertambahan Nilai dan Jumlah Pengusaha Kena Pajak Terhadap Penerimaan Pajak Pertambahan Nilai (Studi Kasus Pada Kantor Pelayanan Pajak Pratama yang Terdaftar Dikantor Wilayah DJP Jawa Barat 1 Periode 2010 - 2015). ejournal.

Karina, Metta. Siti Khairani, 2012. Analisis Restitusi Pajak Pertambahan Nilai Pada Kantor Pelayanan Pajak Pratama Palembar Ilir Barat. ejournal.

Mulyo Agung. 2011. Perpajakan Indonesia seri PPN, PPnBM dan PPh Badan. Jakarta. Penerbit : Lentera Ilmu Cendekia.

Mardiasmo. 2009. Akuntansi Sektor Publik. Penerbit Andi, Yogyakarta.

Mardiasmo. 2011. Perpajakan. Edisi Revisi 2011. Penerbit Andi, Yogyakarta.

M. Nazir. 1988. Metode Penelitian. Penerbit Ghalia Indonesia, Jakarta.

Sianturi, Juventus. 2016. Pengembalian Kelebihan Pembayaran Pajak Pertambahan Nilai Kepada Pengusaha Kena Pajak Pada Kantor Pelayanan Pajak Prtama Padang. Skripsi. Fakultas Hukum : Universitas Andalas. Padang.

Sarah Octavia, Yuniadi Mayowan, Suhartini Karjo. 2015. Analisis Proses Restitusi Pajak Pertambahan Nilai (PPN) di Indonesia. ejournal. 


\section{BALANCE : Economic, Business, Management, and Accounting J ournal Vol. XVII No. 2 |Bulan J uli Tahun 2020}

Siti Resmi. 2014. Perpajakan Teori dan Kasus. Penerbit Salemba Empat, Jakarta.

Suparmoko. 2000. Keuangan Negara : Dalam Teori dan Praktik. Edisi 5. Terbitan BPFE, Yogyakarta.

Sukardji, Untung. 2014. Pokok-Pokok Pajak Pertambahan Nilai Indonesia. Terbitan PT Rajagrafindo Persada, Jakarta.

Suharismi Arikunto. 2013. Prosedur Penelitian : Suatu Pendekatan Praktik. Penerbit Rineka Cipta, Jakarta.

Suharismi Arikunti. 2006. Prosedur Penelitian Suatu Pendekatan Praktik. Penerbit Rineka Cipta, Jakarta.

Sugiyono. 2013. Metode Penelitian Administratif. Penerbit Alfabeta, Bandung.

Wandha Marina Supit, David Paul Elia Saerang, Harijanto Sabijono. 2014. Analisis Restitusi Pajak Pertambahan Nilai Terhadap Penerimaan Pajak Pertambahan Nilai Pada Kantor Pelayanan Pajak Pratama Manado. ejournal.

Yusadi, Icha. 2018. Analisis Restitusi Pajak Pertambahan Nilai Terhadap Penerimaan Pajak Pertambahan Nilai Pada Kantor Pelayanan Pajak Pratama Medan Kota. Skripsi. Fakultas Ekonomi dan Bisnis : Universitas Medan Area. Medan.

Zulnaidi. 2007. Metode Penelitian. Universitas Sumatera Utara. Medan. 